\title{
HUBUNGAN SUPERVISI OLEH KEPALA SEKOLAH DAN KOMPETENSI GURU DENGAN KEPUASAN KERJA DI SEKOLAH DASAR NEGERI SE- KECAMATAN BASO KABUPATEN AGAM
}

\author{
Adi Warman \\ Guru SDN 09 Sungai Cubadak, \\ Koresponden: J I. Raya Bukittinggi-Paya kumbuh Km. $14 \mathrm{Kec}$. Baso Kab. Agam. \\ Email : Adiwaman_042@gmail.com, HP. 081363344987
}

\begin{abstract}
The purpose of this research was to reveal how extend the correlations of Supervision by the Principal and teacher Competencywith job satisfaction at elementary schools in Baso districk Agam.This research used quantitative method which shows the reality and many problems appeared. The population of this research was 201 persons of all elementary schools teachers in distric Baso. Numbers of samples of this research were 60 persons. This research revealed are (1) Supervision by the principal correlated with job satisfaction significantly. The extended of correlation of job satisfaction determined by Supervision ofthe principal as $22 \%$. (2) Teacher competency correlated with job satisfsction significantly. Job satisfaction was determined by teachers teacher competency as 19,4 \%. (3) The supervision by the principal (X1)and teacher comptetency (X2) correlated significantly with job satisfaction at elementary schools in Baso districk Agam, and the extend job satisfsction was determined by supervision the principal and teachers' competency as $29,1 \%$.
\end{abstract}

Key Words: Supervisi, kemampuan guru, kepuasan kerja

\section{PENDAHULUAN}

Peningkatan mutu pendidikan merupakan persoalan penting yang menjadi perhatian utama dalam dunia pendidikan saat ini. Departemen Pendidikan Nasional menyatakan "mutu pendidikan dapat diketahui dengan melihat tingkat pencapaian tujuan pendidikan nasional yang telah dirumuskan". Dalam Undang-undang Nomor 20 tahun 2003 dikemukakan "sistem pendidikan nasional harus mampu menjamin pemerataan kesempatan pendidikan, peningkatan mutu serta relevansi dan efisiensi manajemen pendidikan untuk menghadapi tantangan sesuai dengan tuntutan perubahan kehidupan lokal, nasional, dan global sehingga perlu dilakukan pembaharuan pendidikan secara terencana, terarah, dan berkesinambungan.

Sekolah sebagai lembaga pembentukan sumber daya manusia memiliki beberapa komponen antara lain kepala sekolah, guru, pegawai. Mulyasa (2007:24) menyatakan kepala sekolah merupakan salah satu komponen pendidikan yang berperan dalam meningkatkan kualitas pendidikan.

Herzberg dalam J. Winardi (2004: 49) dengan teori dua faktor menjelaskan bahwa gejala ketidakpuasan dengan pekerjaan, terutama berhubungan dengan faktorfaktor dalam konteks kerja dan lingkungan. 
Menurutnya kebijakan perusahaan, supervisi, gaji, hubungan antar pribadi, dan kondisi kerja merupakan faktor ketidakpuasan seseorang terhadap pekerjaannya. Sejalan dengan itu Nasrullah (1987: 106) menjelaskan faktor yang menyebabkan ketidakpuasan guru antara lain: kurang baiknya kebijakan organisasi, kurang ahlinya supervisor, kurang harmonisnya hubungan antar pribadi, pekerjaan yang tidak sesuai, kurangnya kompetensi guru serta penerimaan gaji yang tidak seimbang dengan beban kerja.

Kepemimpinan kepala sekolah harus mampu mempengaruhi bawahan agar dapat melaksanakan tugasnya dengan baik, pemimpin juga harus memutuskan suatu perkara dengan benar dan adil, agar bawahannya merasa tenang menerima bimbingan dan arahan oleh atasannya sehingga menimbulkan rasa puas terhadap pekerjaannya, hal ini sesuai dengan firman Allah dalam surat Shad ayat 26 sebagai berikut:

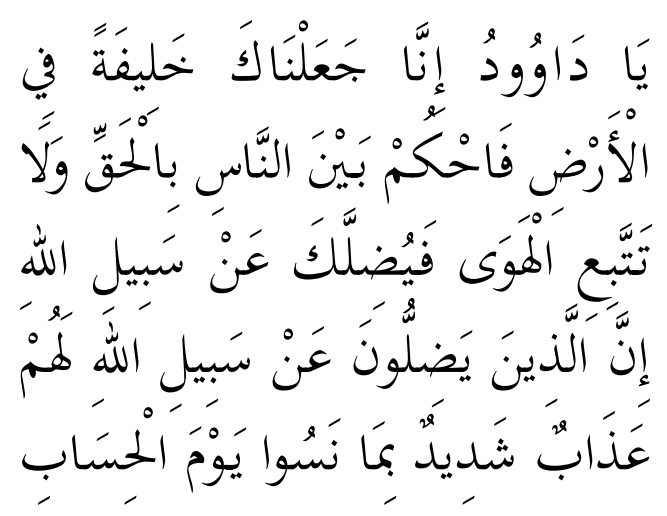

Hai Daud, Sesungguhnya Kami menjadikan kamu khalifah (penguasa) di muka bumi, Maka berilah keputusan (perkara) di antara manusia dengan adil dan janganlah kamu mengikuti hawa nafsu, karena ia akan menyesatkan kamu dari jalan Allah. Sesungguhnya orang-orang yang sesat darin jalan Allah akan mendapat azab yang berat, karena mereka melupakan hari perhitungan (QS 38:26)

Salah satu tugas kepala sekolah adalah sebagai supervisor yang bertugas melakukan pengawasan, pengendalian dan pembinaan, pengawasana dilaksanakan untuk meningkatkan kinerja tenaga kependidikan. Pengawasan dan pengendalian ini dilakukan sebagai kontrol agar kegiatan pendidikan di sekolah terarah pada tujuan yang telah ditetapkan.

Djam'an (2007: 19) mengatakan "dalam rangka membangun manusia Indonesia seutuhnya, guru merupakan pelaksana terdepan". Artinya guru adalah pelaksana proses pembelajaran bagi muridmurid di kelas dalam rangka mencapai tujuan pendidikan. Selanjutnya Tilaar mengemukakan bahwa tanpa mengabaikan faktor-faktor lain guru dianggap sebagai faktor tunggal yang menentukan mutu pendidikan yang diharapkan dapat menghasilkan insan Indonesia yang handal sebagaimana dirumuskan dalam tujuan pendidikan nasional. Untuk mewujudkan tujuan tersebut dibutuhkan guru yang berkompeten di bidang tugasnya.

Wahjosumidjo (2001: 94) menjelaskan bahwa kompetensi merupakan deskripsi dari sifat-sifat atau kualifikasi yang diperlukan untuk memenuhi harapan suatu tugas atau tanggung jawab antara lain: pengetahuan, keterampilan, sikap, menyesuaikan diri dan sifat yang khas lainnya. Berikutnya Djam'an (2007: 18) menyatakan, "empat kompetensi yang harus dimiliki oleh guru yaitu: (1) kompetensi profesional, (2) kompetensi personal, (3) kompetensi sosial, dan (4) 
kemampuan memberi pelayanan sebaikbaiknya yang terdiri atas layanan administrasi pendidikan, layanan instruksional dan layanan bantuan. Sejalan dengan pendapat di atas Thoifuri (2008: 17) mengatakan "guru yang melayani, perlu memiliki kemampuan intelektual, kepribadian, senang dengan tugas dan pekerjaannya serta rela berkorban untuk kepentingan muridnya”.

Berdasarkan observasi awal yang penulis lakukan di lapangan, maka penulis dapat mengidentifikasi permasalahan tentang kepuasan kerja guru SDN di Kecamatan Baso Kabupaten Agam, yaitu : Guru yang kurang puas terhadap pekerjaan,Guru-guru yang kurang puas terhadap lingkungan kerjanya, Guru yang kurang puas terhadap kepemimpinan kepala sekolahnya.

Berdasarkan tiga hal tersebut di atas gejala yang dapat dilihat antara lain adalah: Ditemukan hubungan interpersonal yang belum harmonis dimana terdapat hubungan yang terkotak-kotak dalam satu sekolah sehingga guru tidak merasa nyaman dalam bekerja, guru merasa masih kurangnya penghargaan dan minimnya pembinaan dan bimbingan dari kepala sekolah untuk mengatasi permasalahan mereka, Guru merasa tidak cocok dengan posisi yang diberikan kepala sekolah, keengganan guru menggantikan tugas mengajar rekan sejawat, Guru menganggap penilaian (DP 3) setiap tahun harus meningkat dan guru senior semestinya lebih tinggi dari guru baru, guru senang memperoleh pembahagian jam kerja sesuai batas minimal, guru menganggap upaya mencapai tujuan sekolah sesuai visi, misi yang telah ditetapkan merupakan tugas kepala sekolah, dan sebahagian guru bersikap menunggu hasil keputusan daripada ikut memutuskan, ditemukan guru yang belum mau meningkatkan kemampuan propesionalnya, karena tugas yang dilaksanakan masih terasa berat, jumlah murid dalam satu kelas 37 orang bahkan lebih ditambah lagi dengan tugas administrasi yang harus dikerjakan sendiri karena belum ada petugas tata usaha yang dapat membantunya.

\section{METODE PENELITIAN}

Tempat penelitian ini adalah Sekolah Dasar yang ada di Kecamatan Baso Kabupaten Agam. Waktu penelitian bulan Oktober s/d Nopember 2013.

Populasi penelitian ini adalah semua guru SDN di Kecamatan Baso yang telah menjadi Pegawai Negeri Sipil (PNS) yang aktif mengajar pada tahun 2013/2014. jumlah populasi sebanyak 201 orang yang berada di 28 Sekolah Dasar. Populasi tersebut dikelompokkan berdasarkan strata pendidikan, masa dinas, dan sertifikasi/non sertifikasi. Sampel penelitian ini dipilih dengan menggunakan teknik stratified proportional random sampling. Dari hasil perhitungan yang dilakukan ternyata strata yang paling besar jumlahnya adalah strata tingkat profesional yaitu 85 orang. Maka untuk menetapkan sampel berdasarkan klasifikasi jenjang sertifikasi/non sertifikasi (profesional) yaitu $85 / 201 \times 100 \%=42 \%$. Persentase ini digunakan untuk penetapan jumlah sampel masing-masing strata. Jumlah sampel dalam penelitian ini adalah sebanyak 60 orang yang dipilih secara acak melalui 
undian. Hal ini dilakukan untuk memberi peluang yang sama bagi semua individu yang akan dijadikan sampel.

\section{PEMBAHASAN}

Data variabel kepuasan kerja guru Sekolah Dasar Negeri se-Kecamatan Baso diperoleh dari 37 butir pernyataan. Idealnya skor variabel kepuasan kerja guru Sekolah Dasar se-Kecamatan Baso menyebar antara 129 (terendah) dan 169 (tertinggi). Selanjutnya diperoleh skor rata-rata (mean) sebesar 145,72, skor tengah (median) sebesar 144,00 skor yang banyak muncul (mode) 143 dan simpangan baku (standard deviation) 9.887. Tingkat pencapaian responden pada variabel kepuasan kerja guru Sekolah Dasar Negeri se-Kecamatan Baso adalah hasil bagi rata-rata dengan skor maksimum ideal yaitu $145,72 / 185=0,7876$ atau $78,76 \%$ (termasuk kategori cukup). Hasil ini menunjukkan bahwa kepuasan kerja guru Sekolah Dasar Negeri se-Kecamatan Baso tersebut kategori cukup.

Beberapa hal yang penulis pandang mempengaruhi kondisi ini dengan guru tersebut antara lain berupa:

1. Guru senang memperoleh pembahagian jam kerja sesuai batas minimal, guru menganggap upaya mencapai tujuan sekolah sesuai visi, misi yang telah ditetapkan merupakan tugas kepala sekolah, dan sebahagian guru bersikap menunggu hasil keputusan daripada ikut memutuskan.

2. Ditemukan guru yang belum mau meningkatkan kemampuan profesionalnya, karena tugas yang dilaksanakan masih terasa berat, jumlah murid dalam satu kelas 37 orang bahkan lebih ditambah lagi dengan tugas administrasi yang harus dikerjakan sendiri karena belum ada petugas tata usaha yang dapat membantunya.

3. Sebahagian guru belum mampu menerapkan pembaharuan dalam proses pembelajaran dan pelayanan pada murid yang dilaksanakan di kelas.

4. hubungan interpersonal guru yang belum harmonis dimana terdapat hubungan yang terkotak-kotak dalam satu sekolah sehingga guru tidak merasa nyaman dalam bekerja.

5. guru merasa masih kurangnya penghargaan dan minimnya pembinaan dan bimbingan dari kepala sekolah untuk mengatasi permasalahan mereka.

6. Guru merasa tidak cocok dengan posisi yang diberikan kepala sekolah,

7. Guru menganggap penilaian (DP 3) setiap tahun harus meningkat dan guru senior semestinya lebih tinggi dari guru baru,

Kepuasan kerja merupakan hal yang penting yang dimiliki individu di dalam bekerja. Setiap individu pekerja memiliki karakteristik yang berbeda-beda, maka tingkat kepuasan kerjanyapun berbeda-beda, dan pada akhirnya dampaknya pun tidak sama antara yang satu dengan yang lainnya.

Data variabel supervisi kepala sekolah diperoleh dari 32 butir pernyataan. Idealnya skor variabel supervisi kepala Sekolah Dasar se-Kecamatan Baso menyebar antara 105 (terendah) dan 130 (tertinggi). Selanjutnya diperoleh skor rata-rata (mean) sebesar 119,53 skor tengah (median) sebesar 119.00, 
skor yang banyak muncul (mode) 130 dan simpangan baku (standard deviation) 7,939. Tingkat pencapaian responden pada variabel Supervisi Kepala Sekolah Dasar se-Kecamatan Baso adalah hasil bagi rata-rata dengan skor maksimum ideal yaitu119,53/160 $=0,747$ atau 74,70\% (termasuk kategori cukup). Hasil ini menunjukkan bahwa Supervisi Kepala Sekolah Dasar Negeri se-Kecamatan Baso tersebut cukup.

Ternyata dari tiga indikator supervisi kepala sekolah yang dikaji, ditemukan bahwa ketiga indikator berada pada kategori cukup, maka pada masing-masng indikator ini perlu untuk ditingkatkan atau diperbaiki ke arah yang lebih baik lagi. Hasil analisis ini menunjukkan bahwa supervisi oleh kepala sekolah pada SDN se Kecamatan Baso perlu untuk ditingkatkan ke arah yang lebih baik. Peningkatan supervisi oleh kepala sekolah ini bertujuan agar dalam pelaksanaan tugasnya para guru memiliki rasa tanggung jawab yang tinggi dan kesungguhan dengan pekerjaannya.

Usaha yang dilakukan oleh supervisor apakah dia sebagai kepala sekolah atau pengawas dalam usaha meningkatkan kemampuan guru diperlukan prinsipprinsip supervisi. Prinsip utama yang harus dipedomani dan diterapkan Supervisor menurut Pangaribuan dkk. (2005: 105) sebagai program supervisi disekolah adalah : (1) Ilmiah, yang dikembangkan /dilaksanakan harus benar-benar sitimatis, objektif, dan menggunakan instrument atau sarana yang memberikan informasi yang dapat dipercaya dan dapat menjadi bahan masukan dalam evaluasi dengan situasi belajar mengajar, (2)
Kooperatif program supervisi pendidikan dikembangkan atas dasar kejasama antar supervisor dengan orang yang disupervisi. (3) konstruktif artinya membina guru agar mampu mengambil inisiatif sendiri dalam mengembangkan situasi belajar mengajar.

Data variabel Kompetensi Guru diperoleh dari 37 butir pernyataan. Idealnya skor variabel Kepuasan Kerja Guru Sekolah Dasar Negeri se-Kecamatan Baso menyebar antara 119 (terendah) dan 149 (tertinggi). Selanjutnya diperoleh skor rata-rata (mean) sebesar 136,23 skor tengah (median) sebesar 136,00, skor yang banyak muncul (mode) 123 dan simpangan baku (standard deviation) 8,831. Tingkat pencapaian responden pada variabel Kompetensi Guru Sekolah Dasar Negeri se-Kecamatan Baso adalah hasil bagi ratarata dengan skor maksimum ideal yaitu $136,32 / 185=0,7363$ atau $73,63 \%$ (termasuk kategori cukup). Hasil ini menunjukkan bahwa kompetensi guru pada Sekolah Dasar Negeri se-Kecamatan Baso tersebut cukup.

Sementara menurut Peraturan Menteri Pendidikan Nasional Republik Indonesia Nomor 16 Tahun 2007, sebagaimana dinyatakan pada Lampiran: Peraturan mendiknas Nomor: 16 Tahun 2007 Tanggal: 4 Mei 2007 tentang Standar Kualifikasi Akademik dan Kompetensi Guru, standar kompetensi guru dikembangkan secara utuh ke dalam empat kompetensi, yaitu: (1) Kompetensi Pedagogik, (2) Kompetensi Kepribadian, (3) Kompetensi Sosial, dan (4) Kompetensi Profesional.

Dengan melihat standar kompetensi guru dan kriteria kompetensi guru tersebut, adalah 
sukar berharap bahwa kompetensi guru yang dimiliki berefek pada berkembangnya guru secara profesional bila salah satu atau lebih tahapannya kurang berjalan dengan baik atau tidak dimiliki secara berkesinambungan. Kompetensi guru menjadi tidak bernilai dalam keprofesionalan guru karena lemahnya upaya guru dalam meningkatkan kompetensinya.

\section{ANALISIS}

Data penelitian ini dianalisis dengan menggunakan rumus statistik korelasi dan regresi. Analisis dengan mengunakan teknik statistik ini dapat dilakukan hanya bila data yang akan dianalisis memenuhi beberapa persyaratan yaitu : (1) data masing masing variabel berdistribusi dengan normal, (2) data setiap kelompok (variabel) bersifat homogen, dan (3) garis regresi yang menghubungkan masing-masing variabel bebas dengan variabel terikat bersifat linear.

Pemeriksaan persyaratan analisis dilakukan dengan mengunakan bantuan program SPSS Versi 17.0. Dari hasil analisis dapat simpulkan bahwa Supervisi Kepala Sekolah $\left(\mathrm{X}_{1}\right)$ dan Kompetensi Guru $\left(\mathrm{X}_{2}\right)$ masing-masing memiliki hubungan linier dengan variabel Kepuasan Kerja Guru (Y) serta memenuhi kenormalan dan homogenitas data, karena itu semua persyaratan untuk penggunaan teknik statistik untuk pengujian hipotesis terpenuhi.

\section{Uji Hipotesis}

Hipotesis pertama yang diajukan dalam penelitian ini adalah bahwa "Supervisi Kepala sekolah berhubungan dengan Kepuasan Kerja Guru”terdapat hubungan yang signifikan antara Supervisi Kepala Sekolah dengan variabel Kepuasan Kerja Guru dengan hubungan sebesar 22 \%. dapat diartikan bahwa kepuasan kerja Guru SDN se Kecamatan Baso sebesar 22 $\%$ ditentukan oleh supervisi kepala Sekolah sisanya $78 \%$ ditentukan oleh faktor lain.

Hipotesis kedua adalah "Kompetensi Guru berhubungan secara signifikan dengan Kepuasan Kerja Guru Sekolah Dasar Negeri se-Kecamatan Baso Kabupaten Agam. terdapat hubungan yang signifikan antara Kompetensi Guru dengan variabel Kepuasan Kerja Guru dengan hubungan sebesar 19,4\%. Dengan demikian dapat diartikan bahwa Kepuasan Kerja Guru SDN se Kecamatan Baso sebesar 19,4 \% ditentukan oleh Kompetensi Guru sisanya 80,6 \% ditentukan oleh faktor lain.

Hipotesis ketiga adalah "Supervisi Kepala Sekolah dan Kompetensi guru secara bersama-sama berhubungan signifikan dengan Kepuasan Kerja”. Terdapat hubungan yang signifikan antara supervisi kepala sekolah dan kompetensi guru secara bersama-sama dengan kepuasan kerja guru Sekolah Dasar Negeri se-Kecamatan Baso Kab. Agam berhubungan sebesar 29,1\%. dapat diartikan bahwa kepuasan kerja guru Sekolah Dasar Negeri se-Kecamatan Baso Kabupaten Agam sebesar $29,1 \%$. ditentukan oleh supervisi kepala sekolah dan dan kompetensi guru sisanya $70,9 \%$ ditentukan oleh faktor lain yang tidak diteliti dalam penelitian ini.

Untuk mengetahui hubungan masingmasing variabel bebas tanpa adanya interaksi dari variabel bebas lain dengan vaiabel terikat, dilakukanlah analisis korelasi parsial. Hal ini 
dilakukan dengan mengontrol, dengan salah satu vaiabel bebas dengan vaiabel terikat. variabel $\mathrm{X}_{1}$ berhubungan dengan variabel $Y$ pada saat variabel $\mathrm{X}_{2}$ dikontrol. Hal ini dibuktikan dengan koefisien korelasi sebesar 0.332 dan koefisien determinasi sebesar 0,110. Artinya variabel supervisi kepala sekolah memberikan hubungan sebesar $11 \%$ dengan variabel kepuasan kerja guru Sekolah Dasar Negeri se-Kecamatan Baso Kabupaten Agam dalam keadaan konstan. Besar koefisien korelasi $\mathrm{X}_{2}$ dengan $\mathrm{Y}$ pada saat $\mathrm{X}_{1}$ dikontrol adalah sebesar 0.466 dan koefisien determinasi sebesar 0,217 . Artinya bahwa variabel kompetensi guru memberikan hubungan sebesar 21,7\% dengan variabel kepuasan kerja guru Sekolah Dasar Negeri se-Kecamatan Baso Kabupaten Agam dalam keadaan konstan.

\section{TEMUAN PENELITIAN}

Hasil analisis ini menunjukkan besarnya sumbangan murni yang diberikan oleh masing-masing variabel bebas dengan variabel kepuasan kerja guru Sekolah Dasar Negeri se-Kecamatan Baso Kabupaten Agam positif dengan meningkatnya variabel kepuasan kerja guru Sekolah Dasar Negeri se-Kecamatan Baso Kabupaten Agam.

Analisis data menunjukkan bahwa kepuasan kerja guru dipengaruhi oleh supervisi kepala sekolah dan kompetensi guru baik secara sendiri-sendiri maupun bersamasama. Supervisi oleh kepala sekolah dan kompetensi guru merupakan dua faktor yang sangat penting karena dapat mempengaruhi kepuaasan kerja guru. Supervisi yang dilakukan oleh kepala sekolah dengan baik dan didukung oleh kompetensi guru yang baik pula maka akan dapat lebih meningkatkan kepuasan kerja guru dalam melaksanakan tugasnya.

Herzberg dalam J. Winardi (2004: 89) dengan teori dua faktor menjelaskan bahwa gejala ketidakpuasan dengan pekerjaan, terutama berhubungan dengan faktorfaktor dalam konteks kerja dan lingkungan. Menurutnya kebijakan perusahaan, supervisi, gaji, hubungan antar pribadi, dan kondisi kerja merupakan faktor ketidakpuasan seseorang dengan pekerjaannya.Sejalan dengan itu Nasrullah (1987: 107) menjelaskan "faktor yang menyebabkan ketidakpuasan guru antara lain: kurang baiknya kebijakan organisasi, kurang ahlinya supervisor, kurang harmonisnya hubungan antar pribadi, pekerjaan yang tidak sesuai, kurangnya kompetensi guru serta penerimaan gaji yang tidak seimbang dengan beban kerja”.

\section{PENUTUP}

Berdasarkan data dan hasil analisis yang telah dipaparkan dapat ditarik kesimpulan sebagai berikut: Supervisi oleh kepala sekolah berhubungan secara signifikan dengan kepuasan kerja guru pada Sekolah Dasar Negeri se-Kecamatan Baso Kabupaten Agam sebesar $22 \%$. Ini berarti $22 \%$ varian yang terjadi pada kepuasan kerja guru pada Sekolah Dasar Negeri se-Kecamatan Baso Kabupaten Agam merupakan hubungan dari faktor supervisi oleh kepala sekolah. Kepuasan kerja guru dapat ditingkatkan bila supervisi oleh kepala sekolah diperbaiki.

Kompetensi guru berhubungan secara signifikan dengan kepuasan kerja guru pada 
Sekolah Dasar Negeri se-Kecamatan Baso Kabupaten Agam sebesar 19,4 \%. Ini berarti $19,4 \%$ varian yang terjadi pada kepuasan kerja guru pada Sekolah Dasar Negeri se-Kecamatan Baso Kabupaten Agam merupakan hubungan dari faktor kompetensi guru. Kepuasan kerja guru dapat ditingkatkan bila kompetensi guru diperbaiki.

Secara simultan supervisi oleh kepala sekolah dan kompetensi guru berhubungan secara signifikan dengan kepuasan kerja guru pada Sekolah Dasar Negeri se-Kecamatan Baso Kabupaten Agam sebesar 29,1\%. Ini berarti bahwa $29,1 \%$ variansi yang terjadi pada kepuasan kerja guru pada Sekolah Dasar Negeri se-Kecamatan Baso Kabupaten Agam merupakan hubungan secara bersama dari variabel supervisi oleh kepala sekolah dan kompetensi guru. Semakin baik kedua faktor ini maka kepuasan kerja guru akan meningkat.

Temuan penelitian membuktikan bahwa kepuasan kerja guru mempunyai hubungan yang signifikan dari supervisi oleh kepala sekolah dan kompetensi guru secara parsial maupun secara bersama-sama. Secara statistik supervisi oleh kepala sekolah dan kompetensi guru berhubungan positif dengan kepuasan kerja guru di Sekolah Dasar Negeri seKecamatan Baso Kabupaten Agam. Ini berarti bahwa kepuasan kerja guru dapat ditingkatkan melalui supervisi dan kompetensi guru.

Untuk meningkatkan kepuasan kerja guru, dapat dilakukan dengan memperbaiki proses pembelajaran dalam kelas, melakukan pelatihan terhadap guru-guru terutama pelatihan yang berkaitan dengan strategi pembelajaran. Disamping itu perlu juga memberikan kebebasan kepada guru untuk berkreasi, mendorong para guru dalam mengelola proses belajar mengajar di kelas, memberikan beban kerja yang proporsional, dan memperkaya metode dan model pembelajaran.

Usaha untuk meningkatkan kedua variabel supervisi oleh kepala sekolah dan kompetensi guru ini diharapkan dapat meningkatkan kepuasan guru di di Sekolah Dasar Negeri se-Kecamatan Baso Kabupaten Agam dan Dinas Pendidikan Pemudan dan Olah Raga mempunyai wewenang dan bertanggung jawab untuk membina para kepala sekolah dalam meningkatkan kualitas supervisinya dan membina para guru untuk meningkatkan kompetensi dirinya agar berdampak kearah peningkatan kepuasan kerja.

Untuk memperbaiki kepuasan kerja guru di SDN kecamatan Baso Kabupaten Agam yang perlu dilaksanakan yaitu: Kepala sekolah dalam melaksanakan supervisi harus memperhatikan cara memonitor pelaksanaan tugas guru diantaranya dengan (1) mengamati metode guru mengajar (2) mengamati pelaksanaan evaluasi, pengayaan, dan remedial yang dilakukan guru, (3) memantau guru membuat perangkaat dan cara guru memberi keteladanan pada peserta didik. Memperhatikan cara menilai pelaksanaan tugas guru diantaranya dengan: (1) menganalisa, menginterpretasi hasil analisis kemampuan guru dalam menyusun program, (2) menganalisis dan menginterpretasikan kemampuan guru dalam mengevaluasi dan memberikan keteladanan. Memperhatikan cara membina pelaksanaan tugas guru diantaranya dengan: (1) membantu guru 
menyusun, merancang dan memperbaiki metode dalam meyajikan pembelajaran, (2) membimbing guru memperbaiki cara mengevalusi, dan memberi contoh pada guru cara memberi keteladanan.

Kompetensi lebih ditingkatkan oleh setiap guru. Kompetensi pedagogik diantaranya dengan cara: (1) memperhatikan prinsip pembelajaran, pengembangan kurikulum, (2) menata materi dengan benar sesuai karakteristik peserta didik. (3) melaksanakan prinsip penilaian dan evaluasi sesuai karakteristik pembelajaran. Kompetensi kepribadian diantaranya dengan cara (1) berakhlak mulia, dewasa, berwibawa dan meperhatikan kode etik guru, (2) menghargai peserta didik tanpa membedakan. Kompetensi sosial diantaranya dengan cara: (1) berkomunikasi dengan teman sejawat, orang tua, dan masyarakat. (2) beradaptasi dengan lingkungan kerja. Kompetensi profesional diantaranya dengan cara: (1) mengolah materi sesuai tingkat perkembangan siswa, (2) melaksanakan SK dan KD sesuai tujuan pembelajaran, (3) menguasai dan melaksanakan materi, struktur, konsep, dan pola pikir keilmuan pelajaran yang diampu.

\section{KEPUSTAKAAN ACUAN}

Departemen Agama RI, al-Hikmah, al-Qur'an dan Terjemahnya, Bandung: CV. Penerbit Diponegoro, 2011.
Depdiknas,Manajemen Berbasis Sekolah untuk Sekolah Dasar, Jakarta: Depdiknas, Direktorat Jenderal Pendidikan Dasar dan Menengah, 2001.

Djam'an Satori dkk.,Profesi Keguruan, Jakarta: Universitas Terbuka, 2007.

J. Winardi, Motivasi Dan Pemotivasian Dalam Manajemen, Jakarta: P.T. Rajagrafindo Persada, 2004.

Nasrullah Azis.. "Hubungan antara Keterlibatan dalam Pengambilan Keputusan, Keserasian Hubungan dan pengembangan karir dengan Kepuasan Kerja Dosen-Dosen IKIP Padang" Disertasi Doktor Kependidikan tidak diterbitkan, 1987.

Pangaribuan, dkk., Supervisi Pendidikan, Bandung: Jaya Baru, 2005.

Peraturan Pemerintah Republik Indonesia Nomor 74 Tahun 2008 tentang Guru, BAB I Ketentuan Umum.

Thoifuri, Menjadi Guru Inisiator, Semarang: RaSAIL, 2008.

Wahjosumidjo, Perilaku Kepemimpinan dan Motivasi, Jakarta: Cholia Indonesia, 2001. 